\title{
The Magic Beyond Ritual”- Exploring Raaba Ritual and Ritualization Among Arsi Oromos of Ethiopia
}

\author{
Milkessa Edae Tufa" ${ }^{*}$; Hessan Nagesso Gafarso ${ }^{2}$ \\ ${ }^{1}$ College of Social Sciences and Humanities, Department of Oromo Folklore and literature, Jimma university, Ethiopia \\ ${ }^{2}$ College of Social Sciences and Humanities, Department of Sociology, Jimma University, Ethiopia \\ Email:milkesaedae@gmail.com
}

http://dx.doi.org/10.18415/ijmmu.v5i2.227

\begin{abstract}
The purpose of this (mega) research project is to investigate the Raabaa Ritual and ritualization, one of the indigenous beliefs and Gada system practices in Oromo culture, among the Arsi Oromo. The Raabaa ritual is indigenous ritual practices which exercised by Arsi Oromo according to their Baalli. To this end, the researchers observed the ritual sites where the Raabaa ritual takes place. Besides, an interview with 13 key informants and 5 FGDs were conducted to collect wider data on the subject matter. Methodological the researchers' were employee qualitative approach. The study found out that the Raabaa is being popular in the study area due to various reasons like: firstly, the practicing and living under the shade of Gadaa and belief in the ritual manifestation. The Arsi Oromo are believed to have possessed supernatural powers of empowering and performing various ritual rites to full fill necessary criteria's while passing in the Gadaa system. Secondly, the belief that taking part in ritual ceremonies at all ritual sites of Raabaa is one method of getting relief from these worldly problems such as physical and psychological disordered and to have blessing life. The practices at the Raabaa ritual site also prove the tolerance that exists among some adherents of different religious, Baallis, hookaa and political backgrounds in the study area. According to our finding Raabaa ritual is used to increase awareness of the values of tolerance and understanding. The involvement of the local people, awareness levitation through community serves or education on ritual and ritualization of Raabaa, the practice of ritual and its sites protected areas should be encouraged to sustain and keep the practice.
\end{abstract}

Keywords: Arsi; Baallii; Bokkuu; Gadaa; Raabaa; Ritual

\section{Introduction}

It is unclear when rituals first originated. Some assume that ritual, like dance, music, symbolism, and language, arose in the course of the evolution of primates into man (Bellah., 2003) or even prior to it (Staal., 1989). Be that as it may, biologists and behavioral scientists argue that there are rituals among animals, and this has important implications for our understanding of rituals (Baudy., 2006). Since the end of the nineteenth century, the study of rituals has made considerable strides in anthropology, sociology, and comparative religion (Weinstein \& et al., 2004). 
Dozens of definitions or characterizations proposed by scholars attest to the absence of a basic consensus regarding rituals and to their distinctiveness vis-à-vis other cultural phenomena (Weinstein et al. 2004). The number of definitions proposed is endless, and no one seems to like the definitions proposed by anyone else (Kreinath et al., 2006). Turner (1967), defined rituals; as prescribed formal behavior for occasions not given over to technical routine, having reference to belief in mystical beings and powers; Tambiah (1979), as culturally constructed system of symbolic communication; Kertzer (1988), as symbolic behavior that is socially standardized and repetitive; Kassam (1999), as action to be a form of social practice that emanates from the cultural knowledge system in the sense proposed by Bourdieu (1977); and Rappaport (1999), as the performance of more or less invariant sequences of formal acts and utterances not entirely encoded by the performers.

In the case of these definitions, one might think that the ritual as it is culturally constructed, traditionally sanctioned behaviors, bodily actions and/or speech acts, having its performers as its own audience, marked off from the routine of everyday life, framed, taking place at specific places and/or times, collective, creating/organizing society/social groups, creating change/transition, purposeful (for the participants), repeated, standardized; rehearsed, religious, sacred, and guiding cognition (Kreinath et al., 2006).

It is practically impossible to distinguish the ritual from social action (Leach., 1968). For the followers of Max Weber, social action is nothing but a "meaningful orientation of one's own action to that of the action of another" (Tübingen., 1972). Social actions, if it is to be distinct from mere behavior, are always constituted in terms of norms and meaning that, also hold for ritual praxis (Heidelberg., 2003). In every culture, a clear border separates profane behavior from ritual, which is consistently depicted as a mechanistically discrete and paradigmatic means of socio-cultural integration, appropriation, or transformation (Bell., 1997). In a very preliminary sense, ritualization is a way of acting that is designed and orchestrated to distinguish and privilege what is being done in comparison to other, usually more quotidian, activities. As such, ritualization is a matter of various culturally specific strategies for setting some activities off from others, for creating and privileging a qualitative distinction between the "sacred" and the "profane," and for ascribing such distinctions to realities thought to transcend the powers of human actors (Ibid).

Rituals often have a ceremonial presence, that is to say, they require preparation and a display of various accompanying elements (special garments, colors, olfactory materials, etc.) Ceremonies aim at drawing people's attention to something that is worth noticing, something that is extraordinary in some way. They do not necessarily aim, as rituals do, at signaling to people that there are certain practices, which they should consider crucial to their life or existence (Gruenwald., 2003). The work of Gluckman (1962), Turner (1969), and Bourdieu (1972) were emphasizes on the view that rituals express social relations through ceremonial activities.

The preference of the stage model in an action analysis and interpretation conducted in terms of performance theory (Conquer good., 1991) was selected to analysis the performances of all Raabaa;s Baalli. Above all else it directs attention to the meaning-constituting processes of speech and action within the framework of a symbolic order performed by culture and society (Roach., 1989). Concepts such as 'plot', 'play', 'role', 'gesture', 'expression', 'mimesis', 'scene', and 'framing', but also 'ritual' are-at least in the context of the old world theater tradition-constitutive elements of this model. The advantages are apparent, since this model provides recourse to an elaborate poetics of action, which in practically systematic fashion takes account of a great number of those factors that-in a complex interplay of institution, space, time, actors, observers, texts, things (props), and symbolic media - produce a delimited practice that can be related to culturally preformed and at the same time institutionally linked genre rules of action: a political or religious assembly, a marriage, a play, a banquet, a liturgy, a court proceeding, and so on. 


\section{Statement of the Problem}

In Oromo, the term 'ritual' can be rendered as jila, signifying 'festival; feast; celebration' (Leus 1995). In the traditional Oromo world view, a ritual activity belongs to the realm of uumaa, or the physically created universe. According to Megerssa's (1993), the universe is ordered according to the structuring principles of ayyaana, which determine the shape and destiny of all things in the world. Rituals represent the locus at which the concepts of uumaa (physical creation), ayyaana (principles of nature) and safuu (moral order of culture) converge and through which social order is produced (Kassam., 2011). It should be noted that the Oromo perform prayer ceremonies besides permanently flowing rivers and stagnant water, by the side of big mountains, hills, stones and trees. The land around the Galma and the natural resources on this land are viewed as sacred and are well protected. Oromo society like any society has been conscious of its cultural identity, its relation to nature, and the existence of a powerful force that regulates the connection between nature and society. The words of prayers, blessings and greetings continuously create and recreate connections between the organizational and the cosmological structures (Baxter., 1990).

The numerous studies were conducted on various types of rituals in various parts of the world. For example Sharon Strocchia's comprehensive study of burial rituals in Florence during the fourteenth and fifteenth centuries raised a range of issues, such as significant cultural changes; Dianne OwenHughes notes additional dimensions, such as the confrontation between the mourning styles of men and women; marriage rituals by Weinstein at 2004 in Italy the case of Jewish Style, raised issues such as contents, trends, socio-cultural aspects; Arnold van Gennep (1960). ceremony on pregnancy in India; Aneesa Kassam (2011), studied on Ritual and Classification: A Study of the Booran Oromo Terminal Sacred Grade Rites of Passage; Hinnant., 1977), studied about Guji ritual system; Sirna Gada rituals of Borana (Baxter.,1990; Megarsa., 1993; Kassam., 2011) and Asmarom Legesse (1973), studied on Gada three approaches to the study of African society; Alemayehu Haile (2009). Gada System: The Politics of Tulama Oromo; However as usual the above mentioned researchers have missed the Raabaa Ritual and Ritualization among the Arsi Oromo, Ethiopia. For this reason, we have chosen it. In other words, this can be considered as knowledge, theoretical and conceptual gaps of this study.

\section{Objectives}

$\checkmark$ explore the concept of Raabaa ritual among Arsi Oromo;

$\checkmark$ describe the folkloric elements and characteristics of Raabaa ritual among the Arsi Oromo;

$\checkmark$ identify reaction towards Raabaa ritual and describe its natural setting;

$\checkmark$ explore the socio-cultural significance of Raabaa ritual in study area;

$\checkmark$ analyze the changes and continuities have been seen in the Raabaa ritual performance in the study area; and

$\checkmark \quad$ list out and describe the material culture used during Raabaa ritual and find out social roles and status among participants during Raabaa ritualization.

\section{Research Methodology Research Design}

This research is designed to be qualitative research. It is meant to describe the natures, patterns and contents of Raabaa ritual and ritualization among the Arsi Oromo. Besides, in order to analyze this topic in an in-depth and detailed manner, this study has logically been made to have qualitative study form. 


\section{Sample Size and Sampling Techniques}

The sampling method chosen were purposive or judgmental sampling. This enables researchers to capture the necessary and detail information in study area. Thus, of the Oromo communities' only one .i.e. Arsi is purposely selected for the case analysis, as this site is among the relatively cultural conservative areas. Accordingly, one district and all five Baallis were selected for the sake of the widely functioning of the Raabaa ritual. Moreover, the participants these Baallis are neighborhood. So, they share a common laws, rules, and regulations under the Gadaa system and relatively intact till today. For the primary data collection, the sample size was determined by saturation point. While collecting the data from field the researchers were stay in community until they get enough information.

\section{Data Sources and Methods of Data Collection}

This study utilized essentially qualitative data generated from primary and secondary data sources of information. Primary data were collected via three mechanisms. The first mechanism is Key Informants Interview (KII): Accordingly, 5 knowledgeable local elders, 3 women, and 5 Gadaa leaders (Abba Bokku and Abba Hookka) of all five Baalli were respondents of study. We have selected these respondents, since it is believed that they are an engines of Raabaaa ritual and ritualization. In addition, the researchers contacted experts of culture and tourism office of district to obtain data related to status and trends of practices and reaction towards the Raabaa ritual and ritualization.

The second mechanism is Focus Group Discussions (FGDs). Accordingly, nine (9) FGDs were conducted with local elders among which five (5) FGDs were hold with local elders those who participate in the Raabaa ritual and the others four (4) were with knowledgeable women in general and Cifirees (the wives of Gadamoojjis) in particular those who have great role in the stages of Raabaa ritual activities for all five Baalli. Therefore, a wide range of issues were discussed in line with the FGDs guide pertaining to the study objectives. The discussions were facilitated and led by the researchers taking notes, and the audio records for transcription purpose and further analysis.

The third means was partial participant observation: field visits have been made with all Baalli where and when Raabaa ritual practices take place in the study area; which have enable the researchers to understand the issues never obtained through other tools of data collection, but which has high value in this study. In addition, this means access the researchers to take field work photographs and video that have the real sense of the practice and ritual procedure.

Secondary data were collected from different documents and used as part of the literature review for further analyses of the basic concepts and theories involved in the study. These tasks were accomplished via reclaiming various written materials on the subject matter such as: books and journal articles as well as internet sources.

\section{Methods of Data Interpretation and Analysis}

After the translation of all of the data collected in Afaan Oromo was completed, interview, focus group, and personal observation answers were gathered and organized prior to the start of the analysis. Coding to extract the main themes and relationships in the data was the main method used for the qualitative data. Several coding strategies were used through an inductive, iterative process. An inductive coding process was chosen because of the simple, straightforward nature of the procedure in developing codes and themes directly from the data, whereas, a deductive strategy would have developed codes before analysis began based on a previous theory or assumption (Stellmacher., 2013). The lack of 
restraints and open nature of the inductive coding process was preferred for this case study because of the nature of the research. The data were obtained from the primary foundation of various kinds were also transcribed, put in to thematic and analyzed rationally. Lastly, the validity of the information of the study were cross-checked in parallel with data which were generated from varies sources. Once the accuracy of data is assured, it was analyzed and interpreted, by-and-large, using the qualitative approach. Recorded (audio and video), field photographs and field notes were made use of to substantiate the description and analyses of the subject matter under investigation.

\section{Description of the Study Area}

The research conducted study in the Dodola district of the West Arsi Zone and Oromia regional state, which are located about $320 \mathrm{~km}$ southeast of Addis Ababa, the capital city of Ethiopia. The land coverage of the Dodola district is estimated to $1,612 \mathrm{~km}^{2}$. Dodola is one of the districts in the Oromia Regional state of Ethiopia. It is named after the administrative center of the district, Dodola. Forests cover approximately 37,500 hectares in the Dodola district (Oromia Forest and Wildlife., 2016). The environment is characterized by an Afro alpine ecosystem. A forest, one of the last surviving coniferous forests in the country, dominates the area with a slightly changing forest composition along the altitudinal gradient (Hundera et al., 2007).

It was the capital city of Ganale Awurajja. Ganale's modern administration leadership was begun by Fit Awurary Woldemechael Buie Falama. He was a single charismatic leader who attracted both his nation and the last Ethiopian king, Haile Selassie. Because of his impact and legacy, thousands of Ganale Awraja residents still remember him as their transforming leader who thought ahead of his time. Because he transformed his nation, a nation which never had school, road, telephone, or airport, to test the modern services, by starting modern education in 1940s and the second school 1950s, airport (which disconnected by Dergu), road, and telephone. His nephew, Mekonnen Hassen Buie, who is best known as a great mediator, kept his uncle's legacy and helped to build the first high school in the Awraja Ganale (at that time Dodolaa, Adaabba, Nansaboo, and Kokossa were ruled under Gazei Awraja) in 1961 and get adequate drinking water for his city. But, currently Dodola is part of the West Arsi Zone and Dodola is bordered on the south by Nensebo, on the west by Kokosa, on the north by the Shebelle River which separates it from the Kofele and Gedeb Asasa, and on the east by Adaba. Other towns include Herero.Topographically, Dodola district is at $2400 \mathrm{~m}$ above sea level at the foothills of a mountain range with peaks of over $3700 \mathrm{~m}$. The climate is somewhat cooler than during summer time in central Europe. With increasing altitude the climate gets colder and wetter. Above $3000 \mathrm{~m}$ a.s.l. night frosts are frequent (www.baletrek.com, retrieved on 09 January, 2017).

The highest points in this woreda are Mount Ilale, Mount Korduro and Mount Somkeru. Rivers include the Keresa, Ukuma, Negeso and Gude Yerso which are tributaries of the Shebelle. A survey of the land in Dodola shows that $28.3 \%$ is arable or cultivable (5.1\% of the total was part of state farms), $17.4 \%$ pasture, $48.9 \%$ forest (including 696.76 square kilometers of natural vegetation and 12.24 of man-made forest), and the remaining $5.4 \%$ is considered swampy, mountainous or otherwise unusable. Notable landmarks include the sites of Adele Angato and Hora Birialle. Linseed, onion, vegetables, and fruits are important cash crops.

Industry in the district includes 32 small industries using local raw materials, 25 grain mills, 4 edible oil mills, 2 wood works and one wheat flour mill employing 62 people, as well as 202 wholesalers' 420 retailers and 63 service providers. There were 19 Farmers Associations with 53,958 members and 9 Farmers Service Cooperatives with 7072 members. Dodola has 93 kilometers of all grades of road, for an average road density of 57.7 kilometers per 1000 square kilometers. About $40 \%$ of the total population has access to drinking water. 


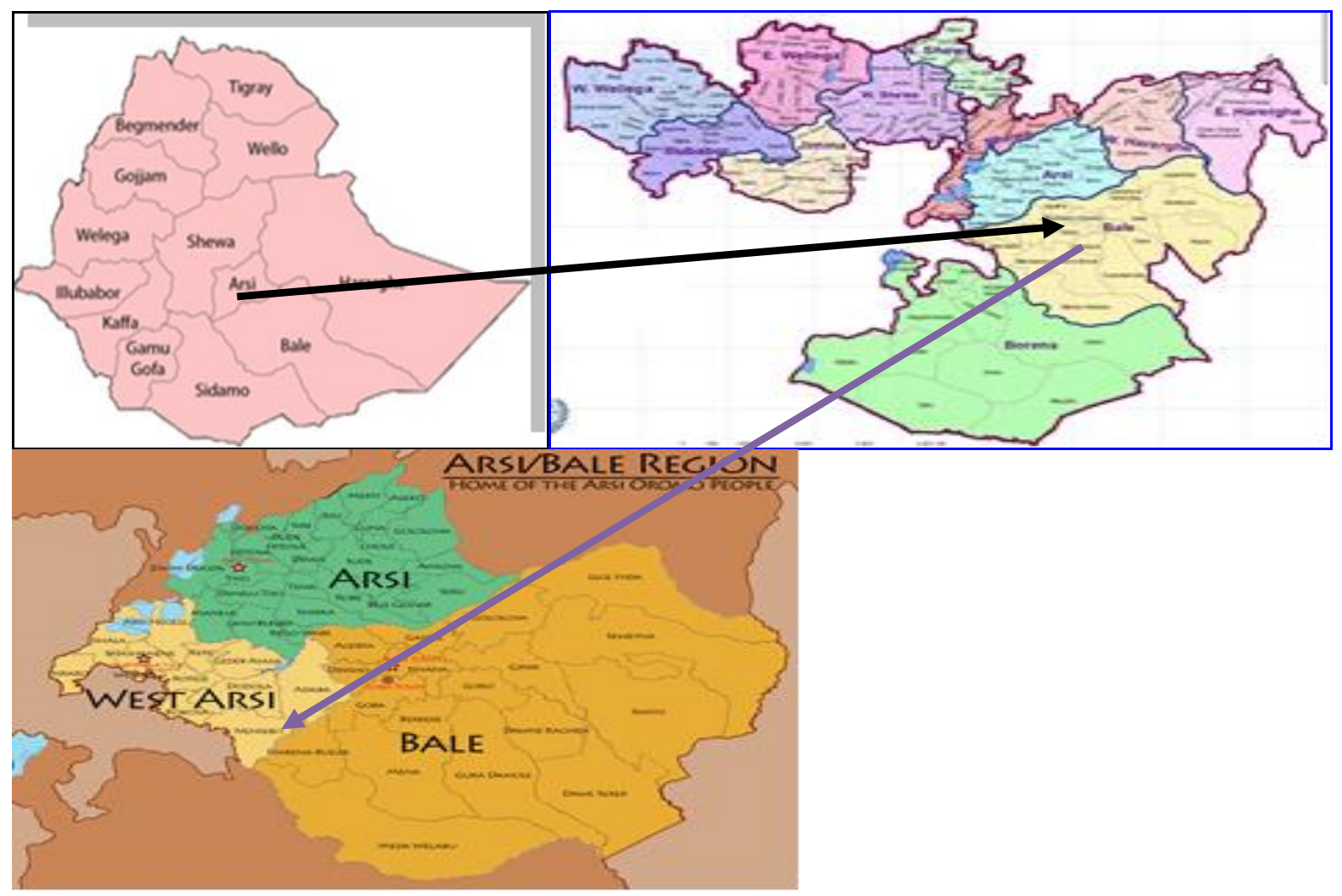

Fig. 1 Map of Study area

Source: Adapted from Finance and Economic Development Bureau of Dodolaa district

\section{Demography}

The 2007 national census reported a total population of this district is 206810 of whom 100,940 were men and 105,870 were women; 34,151 or $17.62 \%$ of its population were urban residents; which is greater than the Zone average of $13.5 \%$. With an estimated area of 1,612.66 square kilometers, Dodola has an estimated population density of 112.2 people per square kilometer, which is greater than the Zone average of 27. The majority of the inhabitants were Muslim, with $88.98 \%$ of the population reporting they observed this belief, while $9.46 \%$ of the population said they practiced Ethiopian Orthodox Christianity, $1.29 \%$ of the populations were Protestant and $1.72 \%$ practiced traditional beliefs.

The two largest ethnic groups reported in Dodola District were the Oromo (91.76\%), and the Amhara (6.14\%); all other ethnic groups made up 2.1\% of the population. Afaan Oromoo is spoken as a first language by $90.33 \%$, and $8.78 \%$ spoke Amharic; the remaining $0.89 \%$ spoke all other primary languages reported.

\section{Climate}

On average, the annual rainfall in Dodola district is $913 \mathrm{~mm}$. Temperatures in the high plain range between 10 and 30 degrees Celsius with an average of about 15 degrees. With increasing altitude, the climate gets colder and wetter. In elevations over $3000 \mathrm{~m}$, night frosts are frequent 
(www.baletrek.com, retrieved on 07 January, 2017). The research area is characterized and affected by four different climate zones, which are Mountains Savannah, Alpine Forest, Erica Forest and Afro-Alpine Zone.

\section{Culture Overview}

The Oromo of Dodola district have many marriage practices. These include Gabbaraa, Walgara, Hawwii, Aseennaa fi Butii. Even though Gabbaraa is highly acceptable and have cultural values. In these sense Gabbaraa marriage custom has its own procedural steps and criteria's to be contented by the groom families. The concept Gabbaraa also derived from the from groom families to bride in cash and materials. These gifts were so called Gonfa or Gabbara in the Oromo of study area. The Dodola community has various institution of helping each other. These include Afoosha, Jigii, Qaboo and Uqqubii associations. Among the Dodola Oromo Gumaa, Bokkuu, Jaarsummaa, ulee gosaa, Qaalluu, and Siiqqee are active mechanisms of conflict resolution and managements. In addition, there are cultural dish such as Caccabsa, Marqaa, Miccirraa and Finiina and Farsoo, Daadhii and Booka in Oromo of study area.

\section{Results and Discussion The Arsi Oromo's Conception of "Raabaa"}

Raabaa is the concept which includes social, economic, and political aspects of the participants or members of the community in which it is practiced. Literally, it is a group of people with definite characteristics and objectives at particular time not uncommonly twice in a year at selected and sacred site. It is also the ritual process that practiced to full fill and transfer Baallii which symbolized power and or a system through which one engaged in Gadaa. Generally, Raabaa is considered as the sign of peace, productivity, development, unity, victory, courageous and healthy among their society throughout a given time.

\section{Steps/Stages of Raabaa Processes}

Raabaa's process has various sequential and remarkable steps. According to data gathered from FGDs the basic step to practice Raabaa ritual is the discussion and decision among Abba Bokku, Abba hookka and saddetta about setting of Raabaa and what ought to be or not. Even though it is not obligation, others would also participate and share their ideas and details. To sum up, discussing and deciding about how, when, where, who, whom, and what should be taken on the upcoming Raabaa by front runners and/or leaders is a typical and considerable fundamental stage in the Raabaa processes. 


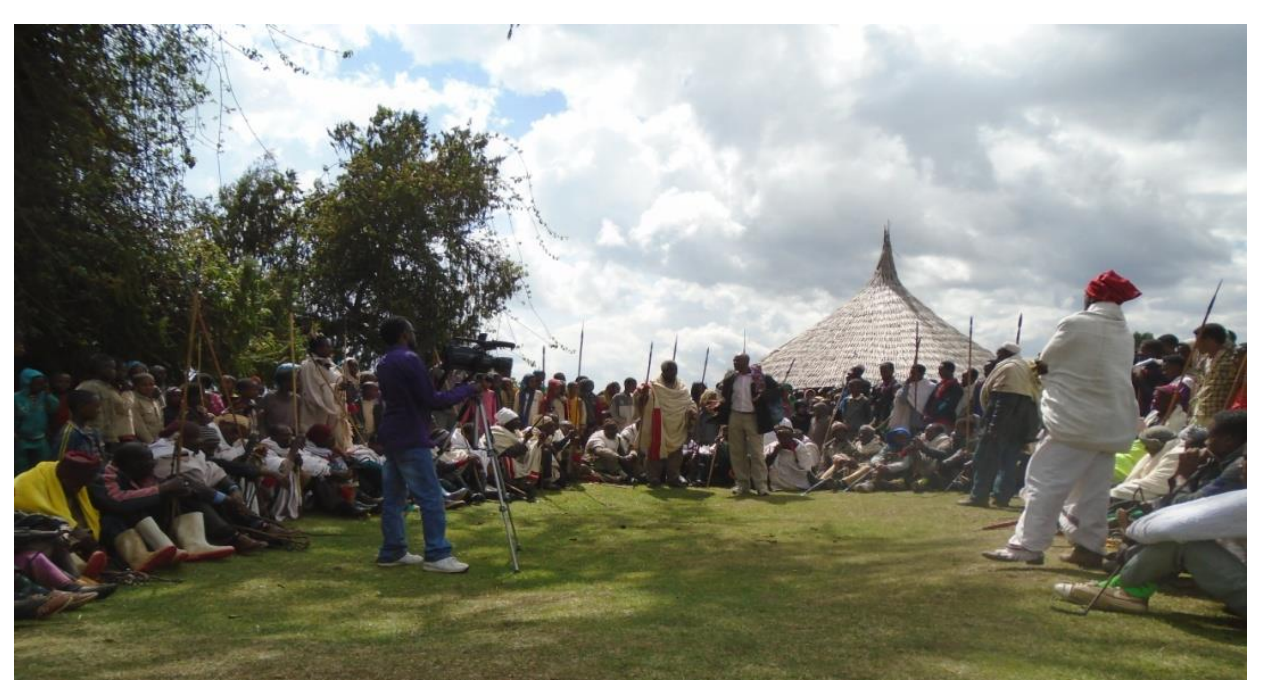

Fig. 2 The get-together of Raabaa ritual Source: Photograph, taken by researchers, February 05, Dodolaa

Along line the decision of leaders and pervasively practiced, the first step is Korma Walargii. As it understandable from its name Korma Walargii is the official opening of the Raabaa ritual. After they slaughter korma walargii stake Xiribbaa and Jila bulchuu. This small peg is the symbol of ownership and the mechanism of avoid bad spirit from community. During that night all gosaas (clans) and Baallii participate in blessing one another and praying waaqaa for peace, unity and fertility. Then in the early morning they move to ritual site and practice 'sirna ulee dhabbannaa' the ceremony of ritual stick.

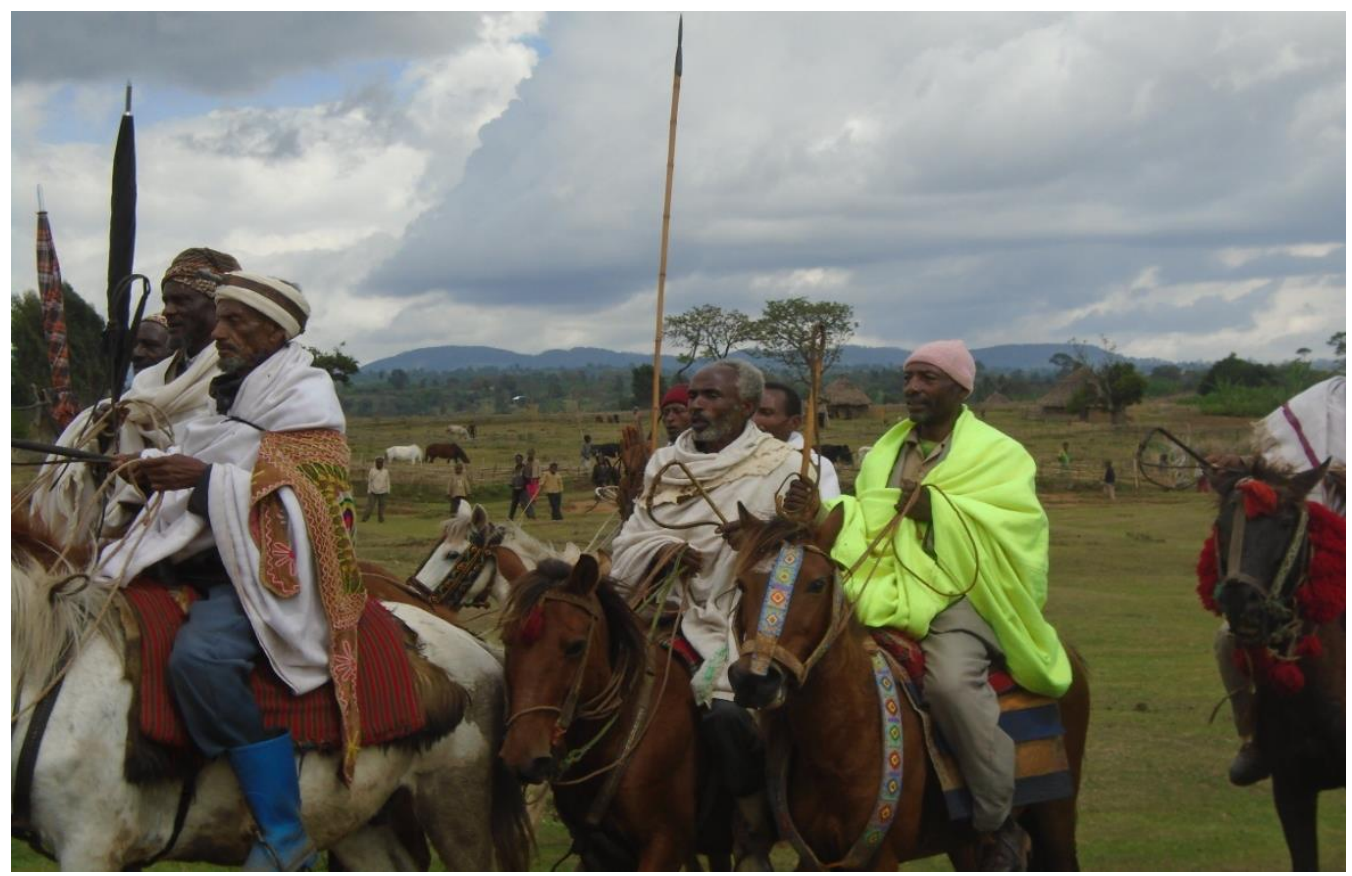

Fig. 3 Gugsii Raabaa (Riding Horse at Raabaa ritual)

Source: Photograph, taken by researchers, February 05, Dodolaa 
After they finish the ulee dhaabbannaa ceremony they proceed to gugsii (riding horse). The stage of gugsii also very appealing and a full of folklore elements such as folk song, geerrarsa, folk-music, eebbaa, dhibayyu and daddarbaa as a means of purification. Besides the participants of gugsii can be categorized in line with age, status and roles they have in their community. As a rule the Raabaa horse must be castrated since it is conditionally forbidden to ride uncast rated horse during Raabaa. Finally, the gugsii is concluded by eebbaa and close the ritual by blessing each other according to Seera Gadaa.

The second step is slaughtering korma Cawwaa at caffee land at another decided time as of the first stage. It isn't allowed to eat conditionally the meat of korma cawwa as it represents cawwaa clan because there is vivid and deviant attachment with the clan though nowadays they are being considered in Gadaa system ${ }^{1}$. Likely to korma walargii there is blessing and praying by staking xiribbaa. In addition the Arsi Oromo connect korma cawwaa to the time when faced drought and famine in history of Oromo that is why they slaughter the bull at 'Caffee'swamp land.

\section{Afaan Oromo}

Oromoo gadi dhaabi

Hidda keenya gadi dhabi

Hirpha Arsii gadi dhaabi

Yaa raaba kottee lubaa

Kottee keenya cimsi

Walitti nu itichi

Raaba raaba kuufaa gabbinaa nuuf godhi May our Raabaa be wealthy

\author{
Equivalent English \\ Stable the Oromo \\ Plant our root \\ Plant the Arsi Hirphaa \\ The Raabaa of kottee luba \\ Strength our leg \\ Strengthen our unity
}

Following korma Cawwa ceremony, the next step in the Raabaa processes is called mana annanii and Korma fuuloo rituals which is taken place commonly in identified home. The ceremony is moderately associated and decorated with milk and milk products. Full of okolee with annan milk and dhibayyuu is attached with staked xiribba which represent being stable like annan canaa ${ }^{2}$. "Canti man keessanii hin bahin" to mean that be blessed or stable like milk. On the day of mana annanii the Raabaa go to the ritual site and ride the horse to finalize the ritual of mana annanii. Besides, on the same occasion, there is a slaughtering of "Korma Fuuloo". The ritual messages of Korma fuuloo slaughtering ceremony is symbolized the ownership, belongingness and controlling their destiny. Generally, at this stage the focus of Raabaa is stability and having identified boundary of social, economic, geographic, and political aspects with their counterparts and/or other communities though others detail activities including foods and drinks are almost the same throughout all stages of the Raabaa rituals.

\footnotetext{
${ }^{1}$ Interview with Baatii Furii,Dodola,Jaunary,07/2017

${ }^{2}$ Interview with Amaan Haajii,Dodola,Jaunary,06/2017
} 


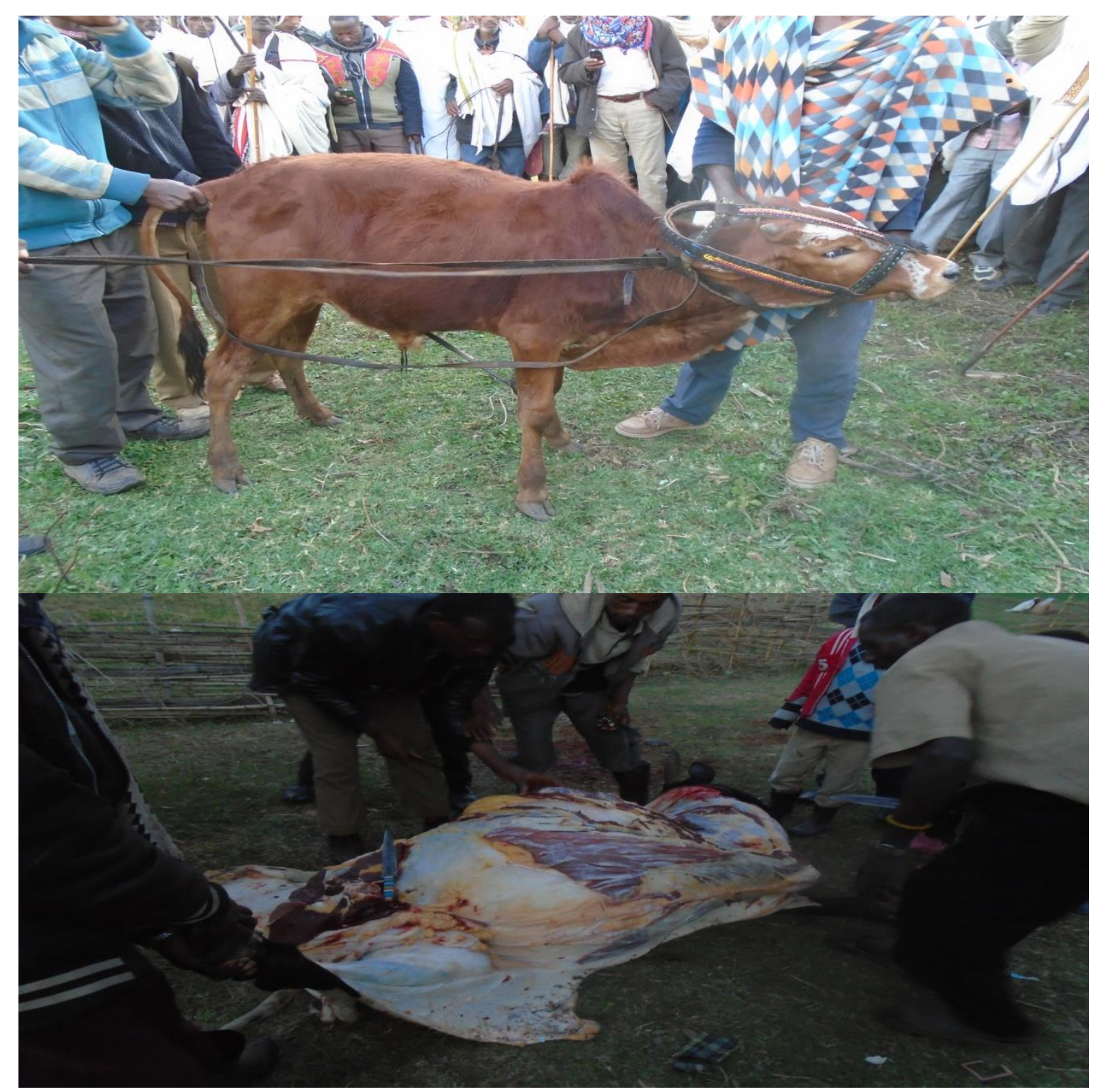

Fig. 4 Korma Fuuloo slaughtering ceremony

Source: Photograph, taken by researchers, February 06, Dodolaa.

The forth step is Korma Harmoo Raabaa rituals. The objective of it is to strengthen the unity among members so as to keep themselves from hostility.

The elders says "Kormi harmoo harmooma, Arsooma" to mean that the strong kinship among the Arsi clans. Korma Harmo ceremony also seen as stage of knowing each other and harmonization. In other words, it is the stage where the focus of ceremony is founding and strengthening the fundamentals like marriage and so forth for further belonging members or "we" integration. Finally, a Korma harmoo raabaa ritual is the stage of harmonization.

The fifth step is sangaa godaa which slaughtered at identified and commonly known cave. The unique activities besides others pervasively known activity is dhadanna saying "Raabni kagodooti" to 
mean that Raabaa belongs to godoo. Godoo means the indigenous cave at which the former Arsi Oromo have designed and formulated seeraa gadaa. According to Raabaa ritual the spainalcord of slaughtered sangaa godaa is never touched or eaten because it represents unity and kinship. Rather, it is given to the abbaa sangaa godaa saying "Quufni mana keettii yaa hafu!” (Let be prosperity in your house).

The six stages in Raabaa ritual processes are known by the name of Re'ee dhawaa which is accompanied with ulee dhabbannaa (staking stick). After the goat is slaughtered, its myriad parts are used for prediction (inner parts of the goat, for instance intestine), blessing (sense organs of the goat (eye, ear, horn, skin, and noise of the goat), and forgiveness (blood of the goat) in their life accordingly. For example, Arsi Oromo takes a part of skin of slaughtered goat which they call it "Meexichaa" and put it on the stem of selected large tree (dhaddacha) to finalize the rituals associated with re'ee dhawaa.

Then the Raabaa go to forest area and cut ulee from Goraa luluffee and then return back to the river. The number and type of ulee is determined by the number of children and status they have in Gadaa system. Then after, all of the participants of the Raabaa rituals stake the stick following Abba bokku and Abba Hokka while calling the name of their Baalli as 'Hii roobalee godoo *5' In Arsi Oromo belief system it's not good fortune if the ulee failed thus it should be stand straightly. Finishing it, they return to their each house up to the next step of Raabaa. The following is some of their Geerrarsaa during .....

\section{Afaan Oromoo}

Birmajii godoo,cumaan kun

Yoo misa deebisuu dhabattee

Aaannan deeisuu dhabattee

Yoo finna deebisuu dhabatte

Yoo cinii balleessuu dhabatte

Yoo Oromo cimsuu dhabatte

Yoo gadaa cimsuu dhabattee

Situ bilaasha *3

Situ duwwaa *3

\section{Equivalent English}

Birmajii godoo may this waste

If it fail to return development

If it fails to return milk

If it fail to return development

If it fail to detect the parasite

If it fail to strengthen the Oromo

If it fail to make stronger the Gadaa

You are nothing

You are empty

The seventh step in the Raabaa ritual is the slaughtering of 'Re'ee Muxuxxee' accompanied with staking 'Ulee luugoo' at intentionally identified 'Malkaa' which is geographically found at the edge of the boundary. This helps them to control their land and expand if possible so as to keep the balance between an increment of the people and the demand. It is also the last stick a Baalii do at the end of their power thereby transfer power to another Baalii. Overall, the step of Raabaa ritual where the Baalii starts to prepare for the transmission of the power to another Baalii at the last stage or step of a single Baalii's Raabaa ritual.

The final or the last step of Raabaa ritual is known by the slaughtering of Dullacha Guurii ceremony. The dullacha guurii is the ceremony which slaughtered to call jila Raabaa and all Baallis to transfer power from one Baalli to another. On the night of Dullacha guurii sadeeta, baallii hookaa and bokkuu and others myriad participants gathered at identified setting by Abbaa bokkuu and all ceremonies of transferring power held. Identifying the strengths and weakness of the Baalli who has power in their hand, giving information and other required materials for the Baalli who is going to take the power, forgiveness for all mistakes as the rules of Gadaaa system, blessings by Abba Bokkuu and others, praying, Geerrarsaa, and other activities are found at this stages extensively and widely. Finally, Inni angoo 
fudhatu isa kennuf uffiseel gonfee bokkuu irraa fudhata. Gadaa kee fixxee jirtaa dabarsi jedhuun ${ }^{3}$. The ceremony of giving Gadaa is followed by sirna dhibayyuu and gonfaa.

\author{
Afaan Oromoo \\ Gadaan gadaa nagahaa siif yaa tatu \\ Ati mandoyyoon bulfadhu \\ Kallachi siyaa bulfattu \\ Ani si ofkalche \\ Gadaan siyaa ofkalchu \\ Ani malkaa siif kenne \\ Karaa siif kenne.
}

\section{Equivalent English}

May your Gadaa be peace Gadaa

You rule the mandooyyoo

May kallachaa rules you

I have blessed you

May Gadaa blessed you

I have gave you the river

I have gave you the road

Generally, the Raabaa rituals of a single Baalli is finished within eight years of one Gadaa system following the above steps and transferred to another Baalli which is done repetitively and accordingly throughout all five Baallis.

\section{The Folkloric Elements in Raabaa Ritual}

As Ritual ingredients Raabaa includes various elements such as folk games, sports, and even some actual combat; we might even view simple at ritual sites. In broad Raabaa can become a ritual for its three parts. These parts are action, performance, and intention. But scientifically we can classify these elements under folkloric genres as the following:

\section{Spiritual Culture}

The ritualistic sign of Raabaa is that the scarifications of valuable things and sacramental entertainments. According to Arsi Oromo elders Raabaa ritual is a full of scarifications at all steps and ritual sites. For instance slathering bull, goat, dhibayyu and daddarbaa are the common sacrifice. Even unfortunately if there is financial problem (Drought, famine and social instability) occurred to the community during Raabaa ritual; they will enforced to the next year/or easily full fill Jinfuu by milk. In addition the ceremony in which the validity of the Raabaa group internment is recognized; not much evidence is exchanged, but the ceremony requires sacrifice in the form of Raabaa ritual purpose. Although Raabaa ritual is embedded in spiritual atmosphere that more complex and none-observable.

\section{Oral Poetry}

On the stage of Raabaa ritual all participants perform oral poetry to express their social status in the community and to thank their waaqaa (God). For example, one of our key informants told us the following poem which indicates the Raabaa and its participants.

\begin{abstract}
Afaan Oromo
Ijoollee culee magaalaa ooluun saalaa Ijoollee bokkuu magalaa ooluun saalaa Raabi soyyee Raabaa siifaa Gadaan geenyaan wawarraqxee
\end{abstract}

\section{Equivalent English}

The sons of culee magaalaa The sons of Bokkuu magalaa being late is shame The Rabii is soyyee Raabaa is good The Gadaa came began to be active

\footnotetext{
${ }^{3}$ Interview withShuree Baatii and Lammii Roobaa,Dodola,Jaunary,07/2017
} 


\section{Material Cultures}

The Raabaa ritual is full filled with different materials which symbolize and attached to Oromo world view. These are Waraana (spear), Bokkuu, Kallacha, Ulee,Kalloo, Wantee (Shield), Erboora, Machallaa, Shore, Warraaqaa and Baallii. The symbolic expression of waraanaa (spear) is war and selfdefense; Bokkuu and kallachaa indicate power. In the process of Raabaa ritual all material cultures have been used to enrich the stage and it serve as the indication of human status.

\section{Performing Folk Arts}

Although Raabaa ritual requires performance folk art as another rituals. The participants taken as those who have perform various actions which have different meanings and implications. Even they utilized folk arts as communication means in Raabaa ritual practice. These performing folk arts are folk dance, folk drama and nonverbal communication Folk arts are very important to hold a certain amount of attention for participants to be attentive. In Raabaa ritual, performance isn't something you do for someone else; you are both the observer and the observed. Thus during the Raabaa ritual all participants are become aware that something is occurring and at what time they have to engage in ritual by decorating their selves with various makeup. In a sense of performance folk art the action not just conventional, but as a substitute a work of art and it is powerful and practical ${ }^{4}$.

\section{The participants of Raabaa Ritual and Their Roles}

The participants of Raabaa ritual area vary in sex, age ,social status and role. All Baallis, hookka,bokkuu,sadeetaa and cifiree are participated in Raabaa ritual according to their seniority, age, Gadaa grade and status. Balliis are Birmajii, Bultuma, Horata, Bahara and Roobalee from senior to junior. Women have the significant role in Raabaa ritual and ritualization. Thus, from very beginning women are the pillar of Raabaa ritual practice. They are active participant of the stage and they are the protocol of Raabaa ritual. Especially the wife of Raabaa has a vital position during Raabaa ritual. She gives her husband horse and blessed him by holding her Siqqee and Okolee. This mandate is given to her by Gadaa in parallel to men.

\footnotetext{
${ }^{4}$ Interview with Meetoo Fayyisaa,Dodola,Jaunary,05/2017
} 


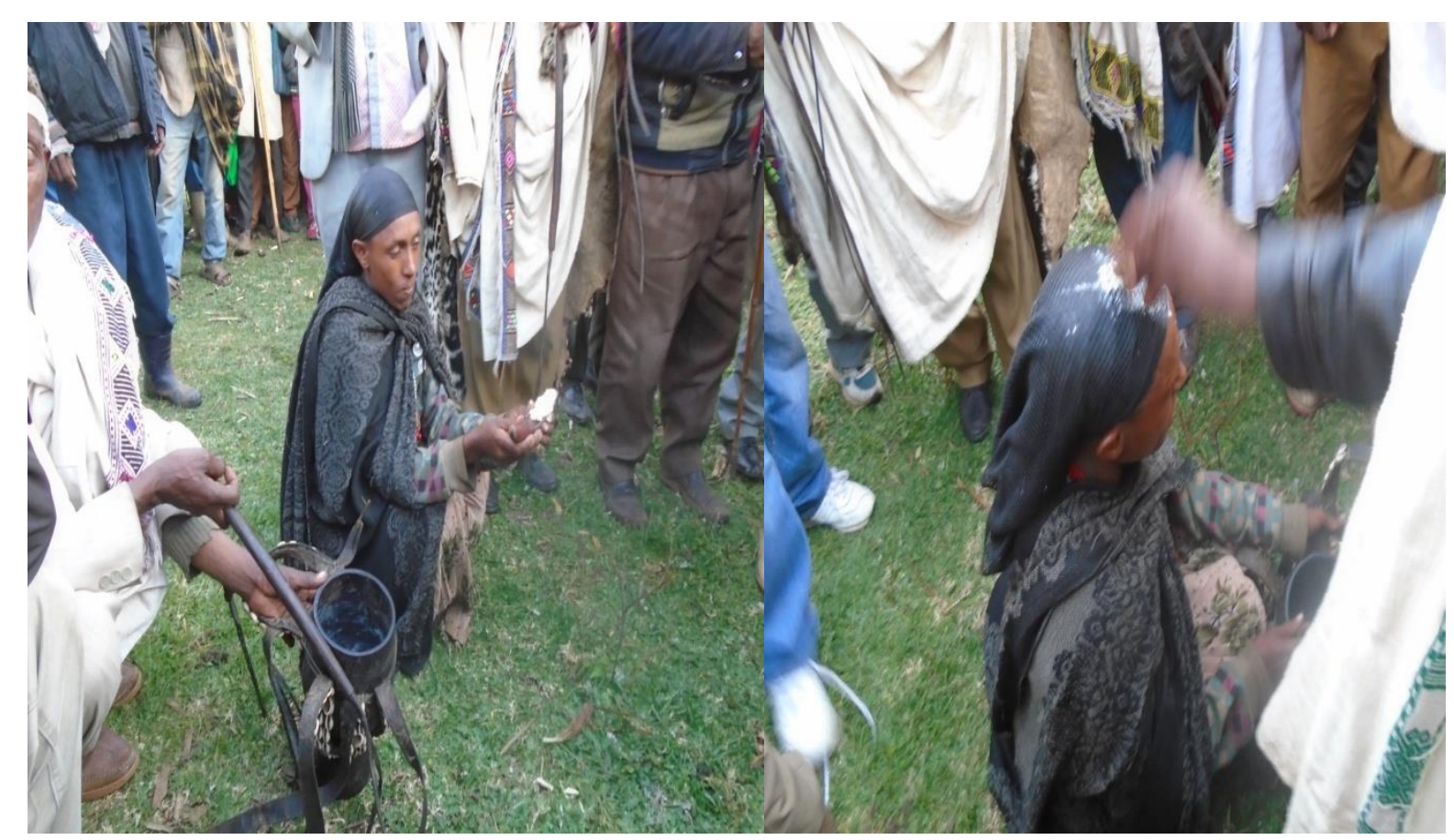

Fig. 5 Women participation and their roles Source: Photograph, taken by researchers, February 07, Dodolaa

Historically these all Baallis has its own implication. Accordingly, Birmajii designed to will blessed wife; Bultuma for wellbeing; Roobalee to claim rain; Horata for hormaata and Bahaara to claim new life. Raabaa can be classified into Raaba ajeesa and Raaba mirga qabne. In their community they identified by their dressing style and roles. The Raabaa ajessaa known by wearing the lather or skin of the wild animals he has killed.

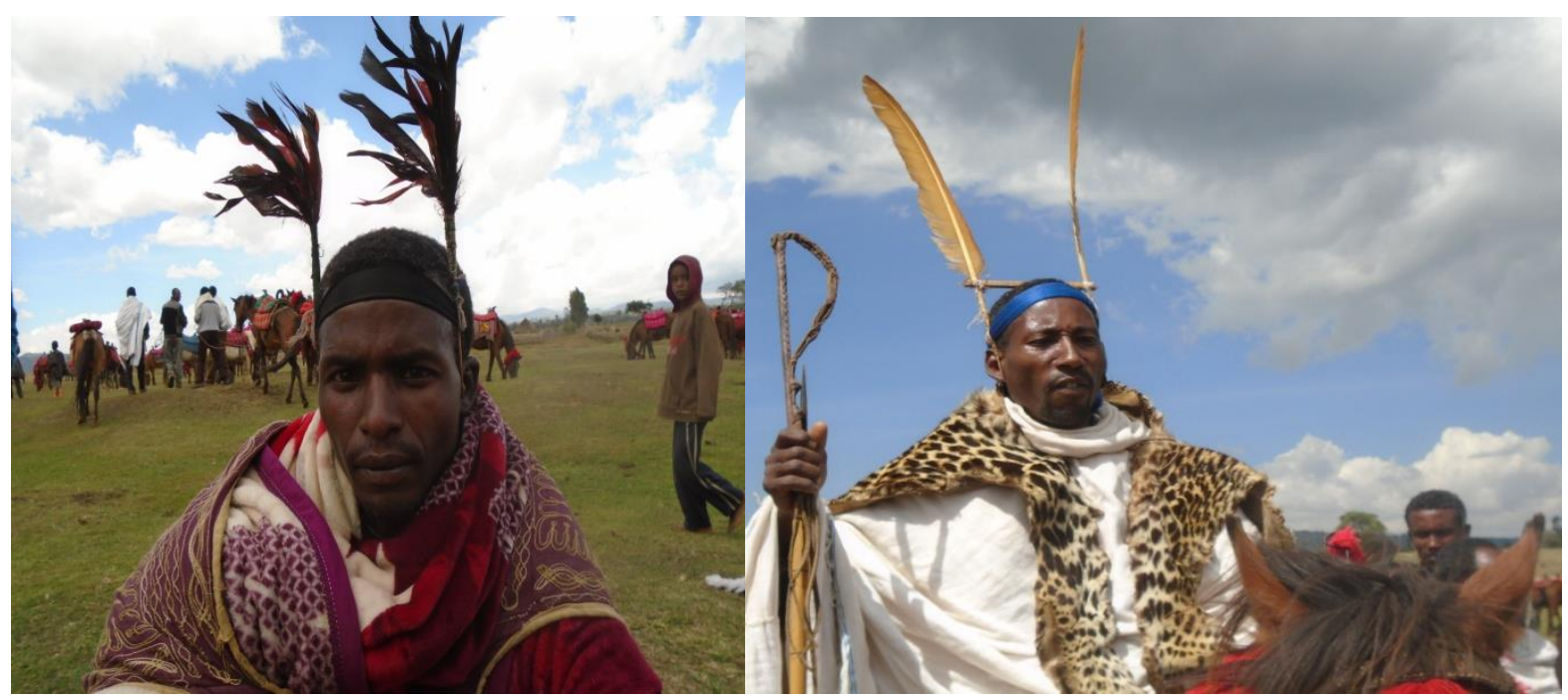

Fig. 6 Raabaa mirga hin qabne

Source: Photograph, taken by researchers, February 05, Dodolaa. 
The wife place is vital in Raabaa ritual. If her husband is abbaa mirgaa/ajeesaa she prepare kalloo,erboora, ballii,alangee, Eeboo, aannoo buufata and decorating all his protocol. If he not ajesaa he wear kalloo waatii and sokora red baallii. Thus, the wife blessing her husband by saying ofkali gadaa. On the day of Raabaa ritual women sing different folk song. For instance;

killan bahee sirraa dahee abbiyyee hoo

Oho my father I have come with killaa and I have got finna from you

Killa guuree sin na uumee abbiiyyee hoo

Oho my creators I have collect killaa

\section{Conclusion}

In this research, we have tried to demonstration in the way Raabaa ritual practiced among the Arsi Oromoo of Dodolaa district. The Raabaa ritual ceremonies and its practices have been explored from folkloric perspective. Thus, Raabaa ritual is the name given to certain group which ruled by and practicing gadaa system as a social institution. The full circulation of Raabaa ritual is ganna sadeet eight year starting from korma walargii qaluu to dullacha guurii.

The folklore of going to Raabaa ritual sites among Arsi is a ritual with a long history. The participants go to Raabaa ritual with variation of reasons, such as, divine and restorative, and to establish mutual affiliation with waaqaa by present galataa. The most dominant motive for Raabaa practice this ritual is appeal and contact with uumaa fi uumamaa be blessed and take skills of leader, through prayers and handing over of power. According to our key informants the foundation of Raabaa ritual was directly connected to seera gadaa.

However, the Raabaa ritual and the followers had faced various oppositions and challenges through time such as confiscation, hiding, and incarceration. Some of the major challenges came from local administrators, modern religious, and spirit of moderation. The researchers have tried to show that the ultimate factor for the coming to dominance of the Raabaa ritual is its spiritual, social, and cultural significance. From spiritual aspect, the Raabaa ritual is believed as to be guarding stick between uumaa and uumaamaa. Socially, it is a gentle ritual for participants of varied religious (Muslims, Christians) and social status backgrounds. Therefore, it strengthened social bond. Culturally, the community used Raabaa ritual to claim, preserve and develop their gadaa.

\section{Recommendation}

The fact that the Oromo Gadaa system is decline from time to time and attempts made to antithesis this circumstances have to focus critically on its corresponding line of research and has to identify concrete measures that has to be boarded on. Thus In the sense the role of social institutions at diverse level, lawful motivations, and scientific documentation efforts to save the endangered Raabaa ritual.

$\checkmark$ Strategies and declarations issued need to elucidate the roles, tasks and Overall mandates of federal, regional and local institutions in relation to the Gadaa in bold and Raabaa ritual in particular as they help to revitalized the overall the Oromo life Jiruu fi jireenyaa.

$\checkmark \quad$ The Oromiyaa culture and tourism office and bureau need to make more elaborate guidelines and proclamations for 'indigenous knowledge in general and Raabaa ritual in particular" as it is very inessential in use and Conservation. 
$\checkmark$ The related governments agents have to clearly indicate the role, clear structure, inter organizational relation and the boundary of different institutions dealing with the Raabaa ritual and work to avoid confusion on Oromo culture and Raabaa ritual in particular.

$\checkmark \quad$ It is also vital to facilitate conditions to ensure the way new generation learn and promote the Raabaa ritual, empowering the community at the grass root level and contribute to its sustainable.

$\checkmark$ Any decisions regarding to Oromo culture have to have a great room for the customary bodies (Bookku, jaarsa biyyaa, cifiree and Hookaa) in the controlling and safeguarding.

$\checkmark$ Empowering community and community-based customary institutions instead of marginalizing them and enforcing and encouraging the real bottom-up approach in the practicing and revitalization of the Raabaa ritual.

\section{Acknowledgment}

The successful completion of this project is achieved as a result of the contributions of various individuals and organizations. First of all, we are thankful to the career and owner of indigenous ritual practices. Thanks also go to the culture and tourism officers of Dodola district without those support the gathering of data and video recording would have been challenging if not impossible. We would also like to extend our thanks to our university, Jimma University for giving us a study leave and facilitating everything. We are also most grateful for Hajji Negesso Geferso the spiritual leader and knowledgeable elder in the study area for giving us the valuable information he provided us. We would also like to forward special thanks for Awol Mustafa for his positive and respect full cooperatives. He had also traveled and guided us to the ritual site/center during field work.

\section{Competing Interest}

The authors declare that there is no competing interests among authors.

\section{References}

Alemayehu H. (2009). Gada System: The Politics of Tulama Oromo. First Edition. Oromia Culture and Tourism Bureau. Volume1.

Asmarom L. (1973). Gada: Three Approaches to the Study of African Society. New York: The Free Press.

Bartles., L. (1990). Oromo Religion, Myth and Rites of the Western Oromo of Ethiopia. An Attempt to Understand. Dietrich Reimer Verlag: Berlin.

Catherine Bell, Ritual Theory, Ritual Practice (New York: Oxford University Press, 1992). Chicago.

Gemetchu M. (1993). "Identity, Knowledge system and the colonizing structure.” Ph.D. Thesis; School of Oriental and African Studies, University of London.

Gennep, Arnold van. The Rites of Passage. (1909). Reprint, London: Routledge \& Kegan Paul, 1960. 
Hinnant JT. (1988). The Gada system of the Guji of Southern Ethiopia. The University of Kertzer. Ritual, politics and power. yale university press, London.

Max Gluckman, Essays on the Ritual of Social Relations (Manchester: Manchester University Press, 1962), pp. 40-41; also cited by Lukes, Émile Durkheim, p. 483, note 45.

Rappaport, R. A. (1999). Ritual and Religion in the Making of Humanity, Cambridge: Cambridge University Press.

Staal, Frits. (1989). Rules without Meaning: Ritual, Mantras and the Human Sciences. New York, etc. Peter Lang.

Tambiah, S. J. (1979). 'A Performative Approach to Ritual', Proceedings of the British Academy, 65: 113-169.

Turner, The Ritual Process: Structure and Anti-Structure (Ithaca, N.Y.: Cornell University Press, 1969), p. 97.

\section{Copyrights}

Copyright for this article is retained by the author(s), with first publication rights granted to the journal.

This is an open-access article distributed under the terms and conditions of the Creative Commons Attribution license (http://creativecommons.org/licenses/by/4.0/). 